\title{
Effect of Early or Delayed Administration of Warfarin with Heparin on Thrombosis in Pulmonary Thromboembolism
}

\author{
Tevfik Ozlu $^{\mathrm{a}}$ Olcay Aycicek ${ }^{\mathrm{a}}$ Mehmet Sonmez $^{\mathrm{b}}$ Yilmaz Bulbul $^{\mathrm{a}}$ \\ Serdar Bedii Omay ${ }^{b}$ Funda Oztuna $^{a}$ Ahmet Durmus $^{b}$ \\ Departments of a Chest Diseases and ${ }^{b}$ Hematology, School of Medicine, Karadeniz Technical University, \\ Trabzon, Turkey
}

\section{Key Words}

Pulmonary embolism $\cdot$ Warfarin $\cdot$ Heparin $\cdot$ Coagulation

\begin{abstract}
Objective: The aim of this study was to investigate the effect of early or delayed warfarin administration with unfractionated heparin (UFH) on coagulation parameters in pulmonary thromboembolism (PTE). Patients and Methods: This study was performed between November 2006 and July 2007. Thirty-three patients with PTE were sequentially slotted to early $(n=16)$ and delayed $(n=17)$ warfarin treatment groups. In the early group, both UFH infusion and warfarin were started simultaneously and in the delayed group, warfarin was added (1-3 days later) based on when partial thromboplastin time reached the therapeutic level with UFH. The proteins C and S, D-dimer, hematocrit levels, and platelet counts for all patients were studied prior to treatment and 6, 24, and $48 \mathrm{~h}$ after warfarin treatment. In order to determine the overall effect of early and delayed warfarin treatment on clot formation, a thromboelastogram was performed simultaneously. Results: In both groups, a similar chronological decrease in protein $\mathrm{C}$ levels reaching maximum at $24 \mathrm{~h}$ with warfarin treatment was observed. However, intragroup or intergroup decreases in protein $\mathrm{S}$ levels were not different. On thromboelastogram, INTEM and EXTEM clotting times were significantly prolonged chrono-
\end{abstract}

\section{KARGER}

Fax +4161306 1234

E-Mail karger@karger.ch

www.karger.com
(C) 2011 S. Karger AG, Basel

1011-7571/11/0202-0181\$38.00/0

Accessible online at:

www.karger.com/mpp logically, but this prolongation was not different between groups. Conclusion: The suppressor effect of warfarin on proteins $C$ and $S$ in the early period of double anticoagulant treatment did not appear to aggravate the risk of thrombosis in patients with PTE in whom warfarin was started simultaneously with UFH.

Copyright $\odot 2011$ S. Karger AG, Basel

\section{Introduction}

Pulmonary thromboembolism (PTE) is a common disease with a high mortality rate of approximately $30 \%$ in untreated patients, which can be reduced to $2-8 \%$ with adequate anticoagulant therapy [1]. The treatment for PTE is usually started with unfractionated heparin (UFH), followed by oral warfarin, when the activated partial thromboplastin time (aPTT) of the patient has reached 1.5- to 2.5 -fold basal value. Initiating oral anticoagulant simultaneously with UFH, regardless of the aPTT value, is another therapeutic option $[1,2]$. However, there is a limited number of studies showing that either the early or delayed addition of oral anticoagulants to UFH treatment has a similar clinical effect [3-6]. Furthermore, it is not clear whether or not there is an increased risk for hypercoagulability secondary to inactivation of proteins $\mathrm{C}$ and $\mathrm{S}$ among patients receiving early 
oral warfarin treatment. This is plausible in view of the short half-life of these inhibitor proteins in comparison with coagulation factors IX and II. Thromboelastography, which has recently been used to measure the activity of both internal end external coagulation pathways, is an in vitro model of the coagulation system. In this study, we used thromboelastography to investigate whether early warfarin treatment, started simultaneously with UFH before reaching the aPTT therapeutic level, causes an increased risk for coagulation among patients with PTE.

\section{Patients and Methods}

All patients with PTE, diagnosed at Karadeniz Technical University School of Medicine between November 2006 and July 2007, who did not have any of the exclusion criteria listed below and who had agreed to take part in the study and given written informed consent, were included in the present study. The exclusion criteria were: massive PTE requiring thrombolytic treatment, use of anticoagulant before admission, administration of UFH and low molecular weight heparin before reaching our hospital and presence of a contraindication to UFH or warfarin. The study was conducted at Farabi Hospital, a tertiary care hospital at Karadeniz Technical University (Turkey), and was approved by the Ethics Committee. All patients were diagnosed using spiral computed tomography of the thorax in the angiography protocol (Siemens Sensation 16 Detector, Erlangen, Germany).

Patients were sequentially slotted into early $(n=16)$ or delayed $(\mathrm{n}=17)$ warfarin treatment groups with respect to the timing of oral anticoagulant warfarin. In the early treatment group, both UFH ( $80 \mathrm{U} / \mathrm{kg}$ bolus and $18 \mathrm{U} / \mathrm{kg} / \mathrm{h}$ infusions, maximum $35,000 \mathrm{U} / 24 \mathrm{~h}$ ) and warfarin (starting at $10 \mathrm{mg} /$ day) were given simultaneously. In the delayed treatment group, the same dose of warfarin was added (1-3 days after the start of heparin) based on when aPTT reached the 1.5- to 2.5-fold of the mean of the normal value with UFH. Both the aPTT and the international normalized ratio (INR) were monitored daily. When the INR was between 2 and 3 on 2 consecutive days, the UFH was discontinued in both groups and the treatment was continued with warfarin alone.

The demographic characteristics of the patients, as well as the clinical properties and risk factors related to thromboembolism were recorded. Parameters that could be affected by the treatment, such as protein C or S (Microplate Absorbance Reader, BioTek Instruments, USA), and D-dimer (STA Compact, Diagnostica Stago, France), as well as the thromboelastogram (Rotem System, Pentapharm $\mathrm{GmbH}$, Germany) were measured both prior to treatment (basal) and after 6, 24, and $48 \mathrm{~h}$ of oral anticoagulant treatment. Intergroup and intragroup differences in clotting time (CT) values obtained from the thromboelastogram and in protein $\mathrm{C}$ and $\mathrm{S}$, and $\mathrm{D}$-dimer values were compared with respect to the change in the time period. In the delayed treatment group, the above-mentioned parameters were measured again, as a second basal value prior to the initiation of oral anticoagulant treatment. Complete blood counts were evaluated daily because of the potential risk for treatment-associated hemorrhage and thrombocytopenia. Intergroup and temporal (basal and at 6, 24, and $48 \mathrm{~h}$ ) hematocrit and platelet counts were compared.
Table 1. Characteristics of patients with PTE at first presentation

\begin{tabular}{|c|c|c|c|}
\hline Parameters & $\begin{array}{l}\text { Early } \\
\text { treatment } \\
(\mathrm{n}=16)\end{array}$ & $\begin{array}{l}\text { Delayed } \\
\text { treatment } \\
(\mathrm{n}=17)\end{array}$ & $\mathrm{p}$ \\
\hline Age, years & $65.5 \pm 15.2$ & $66.94 \pm 11.9$ & 0.764 \\
\hline Female/male & $8 / 8$ & $11 / 6$ & \\
\hline Pulse, bpm & $95.3 \pm 18.6$ & $90.7 \pm 17.5$ & 0.475 \\
\hline \multicolumn{4}{|c|}{ Blood pressure, $\mathrm{mm} \mathrm{Hg}$} \\
\hline Systolic & $119 \pm 23.1$ & $124 \pm 21.7$ & 0.530 \\
\hline Diastolic & $75.9 \pm 14.7$ & $77 \pm 14.3$ & 0.826 \\
\hline Respiratory rate & $22.8 \pm 3.1$ & $23.6 \pm 4.7$ & 0.587 \\
\hline Fever, ${ }^{\circ} \mathrm{C}$ & $36.8 \pm 0.64$ & $36.7 \pm 0.53$ & 0.796 \\
\hline Blood pH & $7.44 \pm 0.04$ & $7.44 \pm 0.47$ & 0.929 \\
\hline \multicolumn{4}{|l|}{ Blood gases, $\%$} \\
\hline $\mathrm{pO}_{2}$ & $82.3 \pm 27.5$ & $65.5 \pm 19.3$ & 0.053 \\
\hline $\mathrm{pCO}_{2}$ & $34.9 \pm 5.6$ & $36.5 \pm 10.3$ & 0.597 \\
\hline $\mathrm{HCO}_{3}$ & $23.7 \pm 4.8$ & $24.3 \pm 4.72$ & 0.715 \\
\hline $\mathrm{SaO}_{2}$ & $94.4 \pm 5.03$ & $90.4 \pm 6.6$ & 0.68 \\
\hline
\end{tabular}

Data are shown as mean \pm SD.

\section{Statistical Analysis}

The Kolmogorov-Smirnov test was used to determine whether the metric data obtained by measurement (continuous data) for the statistical analysis were normally distributed. The analysis of metric data was performed via parametric tests since the data were normally distributed. Metric data of both the early and late treatment groups were compared using Student's t test and the comparison of qualitative data was performed with Fisher's exact test.

Changes in metric data with time in either group (early or delayed groups) were evaluated via variance analysis (paired t test for post hoc) for repeated measurements. Metric data were expressed as the mean \pm standard deviation, whereas discrete data were expressed in numbers (\%). Significance level was assumed to be $\mathrm{p}<0.05$.

\section{Results}

Patient characteristics are given in table 1 . The most common symptoms on presentation were dyspnea: $81 \%$; pleuritic chest pain: $60 \%$; hemoptysis: $24 \%$, and others: $12 \%$. There were no differences between the groups regarding symptoms on presentation and risk factors predisposing to embolism. The emboli were located in the main pulmonary, lobar or segmental arteries in 66,78 and $78 \%$ of patients, respectively. Because of multiple locations, the total exceeded $100 \%$ and the localizations were similar in both groups. 
Table 2. Proteins C and S, D-dimer, hematocrit and platelet count in the early and delayed treatment groups

\begin{tabular}{|c|c|c|c|c|c|c|c|}
\hline & & Basal 1 & Basal 2 & $6 \mathrm{~h}$ & $24 \mathrm{~h}$ & $48 \mathrm{~h}$ & $\mathrm{p}$ \\
\hline Protein C, \% & $\begin{array}{l}\text { early treatment } \\
\text { delayed treatment } \\
\mathrm{p}\end{array}$ & $\begin{array}{r}97.9 \pm 65.8 \\
137.7 \pm 71.8 \\
0.108\end{array}$ & $149 \pm 94.8$ & $\begin{array}{r}81.8 \pm 47.2 \\
122.3 \pm 57.3 \\
0.035\end{array}$ & $\begin{array}{r}78.1 \pm 32.3 \\
118.1 \pm 61.3 \\
0.026\end{array}$ & $\begin{array}{r}85.5 \pm 44.5 \\
146.1 \pm 84.9 \\
0.016\end{array}$ & $\begin{array}{l}0.467 \\
0.364\end{array}$ \\
\hline Protein S, \% & $\begin{array}{l}\text { early treatment } \\
\text { delayed treatment } \\
\mathrm{p}\end{array}$ & $\begin{array}{l}108.7 \pm 36.1 \\
140.2 \pm 44.9 \\
0.035\end{array}$ & $129.7 \pm 28.9$ & $\begin{array}{l}113.9 \pm 36.4 \\
132.6 \pm 47.3 \\
0.215\end{array}$ & $\begin{array}{l}113.7 \pm 46.8 \\
139.8 \pm 54 \\
0.149\end{array}$ & $\begin{array}{l}119.1 \pm 55.5 \\
127.2 \pm 50.8 \\
0.662\end{array}$ & $\begin{array}{l}0.895 \\
0.800\end{array}$ \\
\hline D-dimer, $\mu \mathrm{g} / \mathrm{ml}$ & $\begin{array}{l}\text { early treatment } \\
\text { delayed treatment } \\
\mathrm{p}\end{array}$ & $\begin{array}{r}7.8 \pm 8.4 \\
15 \pm 15 \\
0.180\end{array}$ & $4 \pm 2.1$ & $\begin{aligned} & 7.5 \pm 8.7 \\
& 3.7 \pm 2 \\
& 0.184\end{aligned}$ & $\begin{array}{r}5.1 \pm 4.9 \\
4.5 \pm 3.9 \\
0.767\end{array}$ & $\begin{array}{r}3.6 \pm 3.1 \\
5.4 \pm 3.1 \\
0.217\end{array}$ & $\begin{array}{l}0.272 \\
0.156\end{array}$ \\
\hline Hematocrit, \% & $\begin{array}{l}\text { early treatment } \\
\text { delayed treatment } \\
\mathrm{p}\end{array}$ & $\begin{array}{l}34.5 \pm 5.7 \\
32.3 \pm 5.2 \\
0.354\end{array}$ & $32 \pm 4$ & $\begin{array}{r}34.3 \pm 5.7 \\
31.5 \pm 4.2 \\
0.206\end{array}$ & $\begin{array}{l}33.5 \pm 4.6 \\
31.6 \pm 3.7 \\
0.311\end{array}$ & $\begin{array}{l}33.2 \pm 4.1 \\
32.4 \pm 4 \\
0.631\end{array}$ & $\begin{array}{l}0.262 \\
0.189\end{array}$ \\
\hline
\end{tabular}

Data are shown as mean $\pm \mathrm{SD}$.

\section{Results of Measured Parameters}

Protein $\mathrm{C}$ levels were significantly lower than baseline at 6,24 , and $48 \mathrm{~h}$ after treatment in both groups. A maximum decrease of protein $\mathrm{C}$ was observed at $24 \mathrm{~h}$ of warfarin treatment in both groups. This decrease was determined to be approximately $15 \%$ in the delayed and $21 \%$ in the early treatment group (table 2). However, no significant differences existed between the groups with respect to changes in protein $\mathrm{C}$ values over time.

Nevertheless, no significant difference was detected between the groups with respect to the 6-, 24-, and 48hour values in protein $S$ levels, as well as in chronological changes in comparison with basal values. While maximum suppression in the delayed treatment group was observed at $48 \mathrm{~h}$ of warfarin treatment, no suppression occurred with respect to the protein $S$ values in the early treatment group (table 2).

Although the basal D-dimer value in the early treatment group was lower, no significant difference was detected between the basal value and the values at 6,24 , and $48 \mathrm{~h}$ after treatment. Moreover, there were no significant differences between the changes over time (table 2).

In the early and delayed treatment groups, there was no statistically significant change in hematocrit values with respect to intergroup comparison and time. Although a significant difference was observed in platelet counts according to time in the delayed treatment group, no such difference was observed in the early treatment group. When the two groups were compared, a statistically significant difference in platelet counts was found after 6 and 48 h of warfarin treatment.

\section{Thromboelastography}

There was a significant difference in INTEM CT over time with anticoagulant treatment in both the early and delayed treatment groups (table 3). While basal INTEM CT was $153.9 \pm 25.4 \mathrm{~s}$ in the early treatment group, it became $283.6 \pm 95.7,243.8 \pm 43.7$, and $222 \pm 41.6 \mathrm{~s}$ at 6 , 24 and $48 \mathrm{~h}$, respectively $(\mathrm{p}<0.0005)$. In the delayed treatment group, basal INTEM CT was $140.6 \pm 20.7 \mathrm{~s}$ and at 6,24 , and $48 \mathrm{~h}$, it prolonged to $243 \pm 65.6,234.4$ \pm 56.2 , and $265.9 \pm 87.8 \mathrm{~s}$, respectively $(\mathrm{p}<0.0005)$. In the sample case, while basal INTEM CT was $116 \mathrm{~s}$ (fig. 1a), it prolonged to $255 \mathrm{~s}$ at $6 \mathrm{~h}$ (fig. 1b). However, when the two groups (early and delayed treatment groups) were compared with each other, no significant difference was observed. The change in EXTEM CT was similar to that in INTEM CT (table 3). The change with time was statistically significant in both groups, and no difference was shown between the groups. 

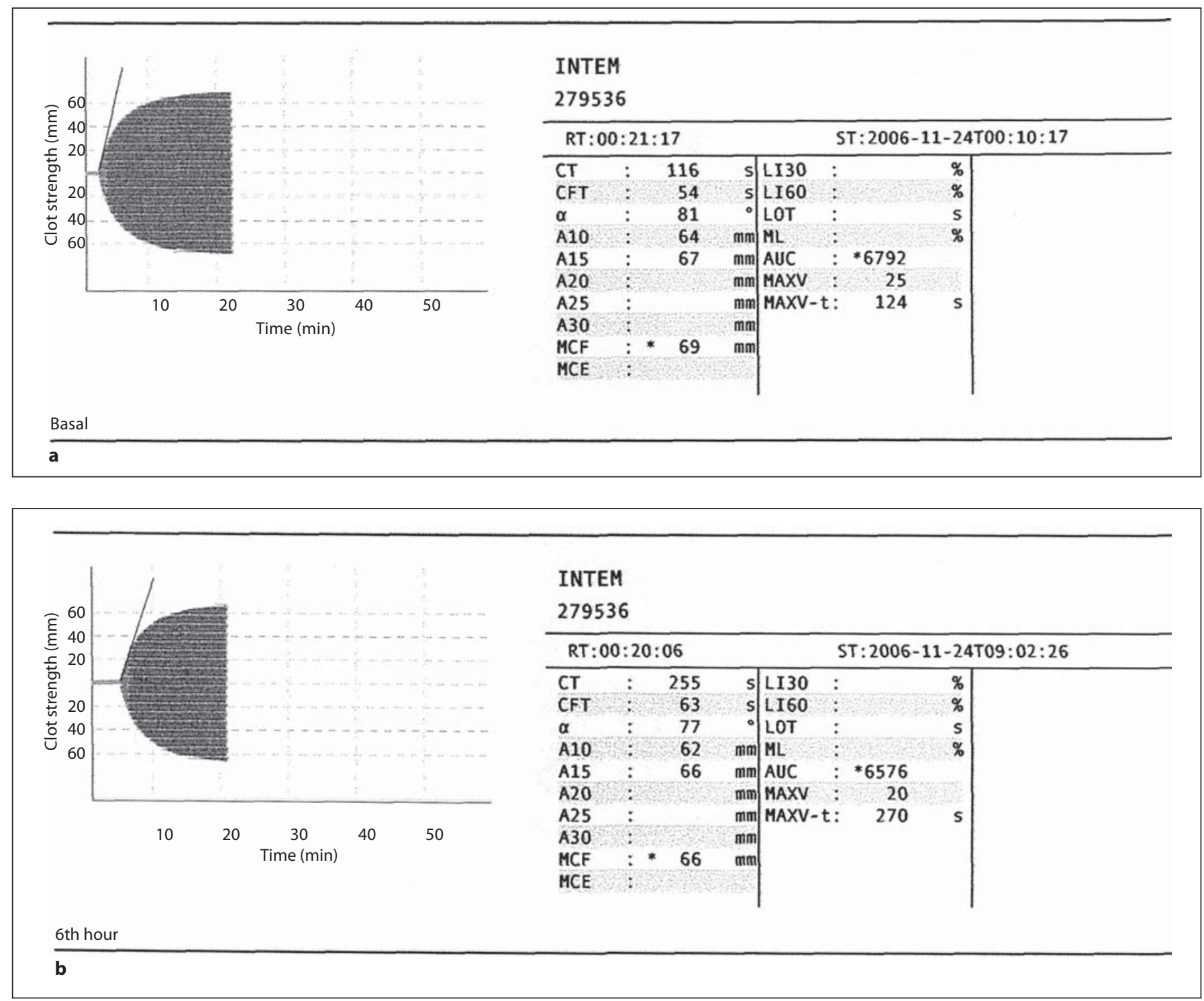

Fig. 1. a Basal thromboelastography before unfractionated heparin treatment (sample case). b Thromboelastography at $6 \mathrm{~h}$ of unfractionated heparin treatment. CFT $=$ Clot formation time.

Table 3. Thromboelastography in the early and delayed treatment groups

\begin{tabular}{|c|c|c|c|c|c|c|c|}
\hline & & Basal 1 & Basal 2 & $6 \mathrm{~h}$ & $24 \mathrm{~h}$ & $48 \mathrm{~h}$ & $\mathrm{p}$ \\
\hline INTEM CT, s & $\begin{array}{l}\text { early treatment } \\
\text { delayed treatment } \\
\mathrm{p}\end{array}$ & $\begin{array}{l}153.9 \pm 25.4 \\
140.6 \pm 20.7\end{array}$ & $256.9 \pm 54$ & $\begin{array}{r}283.6 \pm 95.7 \\
243 \pm 65.6 \\
0.162\end{array}$ & $\begin{array}{l}243.8 \pm 43.7 \\
234.4 \pm 56.2 \\
0.603\end{array}$ & $\begin{array}{l}222 \pm 41.6 \\
265.9 \pm 87.8 \\
0.085\end{array}$ & $\begin{array}{l}<0.0005 \\
<0.0005\end{array}$ \\
\hline EXTEM CT, s & $\begin{array}{l}\text { early treatment } \\
\text { delayed treatment } \\
\mathrm{p}\end{array}$ & $\begin{array}{r}73 \pm 27.8 \\
68.3 \pm 22.3\end{array}$ & $85.8 \pm 42.1$ & $\begin{array}{l}82.8 \pm 37.1 \\
81.7 \pm 32.1 \\
0.927\end{array}$ & $\begin{array}{l}95.7 \pm 28.3 \\
84.5 \pm 37.4 \\
0.345\end{array}$ & $\begin{array}{r}96.5 \pm 38.9 \\
104.7 \pm 33.6 \\
0.53\end{array}$ & $\begin{array}{l}0.012 \\
0.050\end{array}$ \\
\hline
\end{tabular}

Data are shown as mean $\pm \mathrm{SD}$. 


\section{Adverse Events}

In the early treatment group, 1 patient had hematuria, another UFH-dependent thrombocytopenia not requiring cessation of UFH and a 3rd had both nonmajor subdermal hematoma and hematuria. In the delayed treatment group only 1 patient had hematuria. During the hospitalization period, urinary tract infection developed in 3 patients in the early and hospital-acquired pneumonia developed in 1 patient in the delayed treatment group. The mean hospitalization period was $10 \pm 1.8$ days for the early and $13 \pm 3.2$ days for the delayed treatment group $(\mathrm{p}=0.02)$.

\section{Discussion}

It is known that the oral anticoagulant warfarin has a suppressor effect on the activity of the natural anticoagulant proteins, protein $\mathrm{C}$ and its cofactor protein S. This suppressor effect of warfarin begins before its inhibitory effect on vitamin $\mathrm{K}$-dependent coagulation factors (factors II, VII, IX, and X) [7]. Weiss et al. [8] reported a rapid decrease in the level of protein $\mathrm{C}$ at the beginning of warfarin treatment, while other vitamin K-dependent coagulation factors had higher levels. Equally, Sakata et al. [9] observed a significant reduction in protein $\mathrm{C}$ and factor X levels in patients with INR $>$ 2.5. In our study, we did not monitor the chronological change in protein $\mathrm{C}$ and $\mathrm{S}$ values in comparison with basal values in both the early and delayed treatment groups. The difference in protein $\mathrm{C}$ levels found between the two groups at 6,24 , and $48 \mathrm{~h}$ may be related to the lower basal protein $\mathrm{C}$ levels in the early treatment group. However, the rate of decline in protein $\mathrm{C}$ levels was not different between groups.

There are limited studies investigating the early prothrombotic effect of warfarin. The reason for using thromboelastograms in the present study was to observe the net effect of the two opposing mechanisms of warfarin under in vitro conditions, which are similar to in vivo conditions. As expected, INTEM CT and EXTEM CT significantly prolonged in both early and delayed groups after the start of anticoagulant treatment, however, the prolongation of INTEM CT and EXTEM CT was not different between the groups at 6,24 , and $48 \mathrm{~h}$ after treatment. These findings suggest that despite the lower levels of protein $C$ in the early treatment group at 6,24 , and $48 \mathrm{~h}$, this difference did not increase the tendency for coagulation based on the thromboelastogram, which is an in vitro model of the coagulation system.
In a study by Mohiuddin et al. [4] investigating the safety and efficacy of starting warfarin early or late, no difference was found between the two groups regarding the duration of treatment, hemorrhage, recurrent thromboembolic events, and mortality rate prior to the discharge of patients and the duration of hospitalization. Equally, in another study by Gallus et al. [3] with preexisting thromboembolism no significant difference was observed between the early and delayed wafarin groups regarding the recurrence of venous thromboembolism, mortality, and hemorrhagic complications. Similar results were also reported in two other studies $[5,6]$.

Heparin may rarely cause thrombocytosis in addition to its more frequent thrombocytopenic effect. This thrombocytotic effect is considered to be associated with potentiation of megakaryocytopoiesis with the inhibition of platelet factor 4 [10]. Cases with thrombosis, particularly resulting from the use of low molecular weight heparin, have been reported $[11,12]$. In the present study, the platelet count increased significantly over time in the delayed treatment group.

Thrombocytopenia developed in 1 patient (3\%) in our study in the early treatment group on the 3rd day of treatment. The rate of thrombocytopenia was reported as $6 \%$ by Kakkasseril et al. [13] in patients receiving intravenous UFH and seen more commonly in patients treated for more than 10 days. It is thought that nonimmune heparin-induced thrombocytopenia is caused by a direct agglutinating effect of heparin on platelets. The second type, immune-mediated thrombocytopenia (formerly called type II HIT, now simply HIT) is associated with an increased risk of thrombosis and usually develops between 5 and 14 days after heparin treatment $[14,15]$. A decrease in platelet counts exceeding $50 \%$ is particularly indicative of HIT $[16,17]$.

\section{Conclusion}

Our results showed that the suppressor effect of warfarin on proteins $\mathrm{C}$ and $\mathrm{S}$ in the early period did not aggravate the risk of clot formation, as assessed by thromboelastography, in patients in whom warfarin was started simultaneously with UFH. Moreover, early addition of warfarin might reduce the incidence of complications resulting from UFH treatment, such as hemorrhage, thrombocytopenia, allergic reactions, as well as hospital-acquired infections and hospital costs by shortening the duration of hospitalization. 


\section{References}

1 Guidelines on diagnosis and management of acute pulmonary embolism. Task Force on Pulmonary Embolism, European Society of Cardiology. Eur Heart J 2000;21:1301-1336.

$>2$ Hirsh J, Hoak J: Management of deep vein thrombosis and pulmonary embolism: a statement for healthcare professionals. Council on Thrombosis (in consultation with the Council on Cardiovascular Radiology), American Heart Association. Circulation 1996;93:2212-2245.

3 Gallus A, Jackaman J, Tillett J, Mills W, Wycherley A: Safety and efficacy of warfarin started early after submassive venous thrombosis or pulmonary embolism. Lancet 1986; ii:1293-1296.

4 Mohiuddin SM, Hilleman DE, Destache CJ, Stoysich AM, Gannon JM, Sketch MH Sr: Efficacy and safety of early versus late initiation of warfarin during heparin therapy in acute thromboembolism. Am Heart J 1992; 123:729-732.

5 Hull RD, Raskob GE, Rosenbloom D, Panju AA, Brill-Edwards P, Ginsberg JS, Hirsh J, Martin GJ, Green D: Heparin for 5 days as compared with 10 days in the initial treatment of proximal venous thrombosis. N Engl J Med 1990;322:1260-1264.
6 Leroyer C, Bressollette L, Oger E, Mansourati J, Chèze-Le Rest $C$, Nonent $M$, Buchmuller A, Tardy B, Decousus $\mathrm{H}, \mathrm{Pa}-$ rent F, Simonneau G, Juste K, Ill P, Abgrall JF, Clavier J, Mottier D: Early versus delayed introduction of oral vitamin $\mathrm{K}$ antagonists in combination with low-molecular-weight heparin in the treatment of deep vein thrombosis. a randomized clinical trial. The ANTENOX Study Group. Haemostasis 1998;28: 70-77.

7 Hirsh J, Dalen JE, Anderson DR, Poller L, Bussey H, Ansell J, Deykin D, Brandt JT: Oral anticoagulants: mechanism of action, clinical effectiveness, and optimal therapeutic range. Chest 1998;114:445S-469S.

8 Weiss P, Soff GA, Halkin, Seligsohn U: Decline of proteins $\mathrm{C}$ and $\mathrm{S}$ and factors II, VII, IX and $\mathrm{X}$ during the initiation of warfarin therapy. Thromb Res 1987;45:783-790.

$\checkmark 9$ Sakata T, Kario K, Matsuo T, Katayama Y, Matsuyama T, Kato H, Miyata T: Suppression of plasma-activated factor VII levels by warfarin therapy. Arterioscler Thromb Vasc Biol 1995; 15:241-246.

10 Camou F, Viallard JF, Caubet O, Pellegrin JL: Thrombocytosis: adverse effect of heparin treatment. Presse Med 2006;35:58-60.
1 Hummel MC, Morse BC, Hayes LE: Reactive thrombocytosis associated with enoxaparin. Pharmacotherapy 2006;26:1667-1670.

12 Liautard C, Nunes AM, Vial T, Chatillon F Guy C, Ollagnier M, Deseotes J: Low-molecular-weight heparins and thrombocytosis. Ann Pharmacother 2002;36:1351-1354.

13 Kakkasseril JS, Cranley JJ, Panke T, Grannan $\mathrm{K}$ : Heparin-induced thrombocytopenia: a prospective study of 142 patients. J Vasc Surg 1985;2:382-384.

14 Cooney MF: Heparin-induced thrombocytopenia: advances in diagnosis and treatment. Crit Care Nurse 2006;26:30-36.

15 Franchini M: Heparin-induced thrombocytopenia: an update. Thromb J 2005;3:14.

16 Mureebe L, Silver D: Heparin-induced thrombocytopenia: pathophysiology and management. Vasc Endovascular Surg 2002; 36:163-170.

17 Cipolle RJ, Rodvold KA, Seifert R, Clarens R, Rainirez-Lassepas M: Heparin-associated thrombocytopenia: a prospective evaluation of 211 patients. Ther Drug Monit 1983;5: 205-211. 